\title{
36. BASALT FROM THE COCOS PLATE, SITE 487, LEG 66: PETROLOGY AND GEOCHEMISTRY 1
}

\author{
J. L. Joron, Laboratoire de Géochimie comparée et systématique, Université de Paris VI, 75230 Paris, France, \\ and Groupe des Sciences de la Terre, Laboratoire Pierre Süe, CEN, Saclay 91191 Gif/Yvette, France \\ H. Bougault, Centre Océanologique de Bretagne, CNEXO, B.P. 337, 29273 Brest, France \\ and \\ R. C. Maury and J. F. Stephan, Université de Bretagne Occidentale, 29283 Brest, France
}

\begin{abstract}
Major oxide and trace element determinations of the composition basalts from the bottom of Hole 487, together with microprobe analyses of their minerals (olivine, magnesiochromite, salite, and plagioclase), prove that they are depleted oceanic tholeiites.
\end{abstract}

\section{LITHOLOGY}

Seven meters of basalt, overlain by 150 meters of sedimentary layers, were recovered at Site 487 on the Cocos Plate at $99^{\circ} 09^{\prime} \mathrm{W}$ and $15^{\circ} 51^{\prime} \mathrm{N}$, close to the Central America Trench off Acapulco. Three basalt samples from Section 487-20-1 $(55-58 \mathrm{~cm}, 72-78 \mathrm{~cm}$, and 82-89 $\mathrm{cm}$ ) were available to us. They belong to the same magmatic unit and differ from another only in degree of alteration: the $55-58 \mathrm{~cm}$ interval is the freshest and the $82-89 \mathrm{~cm}$ interval the most altered. The petrographic features are those commonly observed in ocean floor basalts: they are subaphyric, with plagioclase phenocrysts dominant over olivine phenocrysts, and pyroxene phenocrysts are apparently absent. The groundmass is composed of abundant plagioclase microlites, associated with olivine, clinopyroxene and rare spinel microcrysts, and partly devitrified brown glass.

\section{MAJOR ELEMENT COMPOSITION}

The three analyses in Table 1 differ only by minor variations probably due to alteration: $\mathrm{SiO}_{2}$ and the amount of the loss on ignition increase from $55-58 \mathrm{~cm}$ to $82-89 \mathrm{~cm}$ with petrographic indications of alteration. All the major element concentrations fall in the range of typical low-potassium ocean floor tholeiites. The FeO*/ $\mathrm{FeO}^{*}+\mathrm{MgO}$ ratio is close to $0.5(0.48-0.53)$, indicating that Site 487 basalt has not suffered extensive fractionation of olivine; the freshest sample $(487-20-1,55-58 \mathrm{~cm})$ shows a slightly undersaturated character $(0.12 \%$ normative nepheline).

\section{MINERALOGY}

Selected microprobe analyses are given in Table 2.

Olivines. Their composition is rather constant $\left(\mathrm{Fo}_{88}\right)$, without noticeable variation from the core to the rim in the phenocrysts; the smallest microlites are slightly ironenriched $\left(\mathrm{Fo}_{85}\right)$.

\footnotetext{
${ }^{1}$ Initial Reports of the Deep Sea Drilling Project, Volume 66.
}

Spinels. They are represented only by tiny octahedra of magnesiochromite, $\mathrm{Cr}$ being the dominant trivalent cation and $\mathrm{Mg}^{2+}>\mathrm{Fe}^{2+}$ (Table 2, Analyses 7 to 9). This spinel composition is commonly found in basalts from midoceanic ridges and ocean floors and may be typical of slightly to moderately fractionated lavas with $\mathrm{FeO}^{*} / \mathrm{FeO}^{*}+\mathrm{MgO}$ ratio less than 0.57 and $\mathrm{Cr}$ content greater than $350 \mathrm{ppm}$ (Sigurdsson and Schilling, 1976).

Clinopyroxenes. Their occurence is restricted to the groundmass, where they are rather scarce. They are characterized by high $\mathrm{Al}_{2} \mathrm{O}_{3}, \mathrm{TiO}_{2}$, and $\mathrm{CaO}$ content and plot into the salite field of the $\mathrm{Ca}-\mathrm{Mg}-\mathrm{Fe}$ diagram, usually typical of clinopyroxenes from alkali basalts; this fact must be correlated with the slightly undersaturated character of the whole rock. These salites are relatively iron-rich $\left(\mathrm{Fs}_{15}-\mathrm{Fs}_{20}\right)$.

Plagioclases. The phenocrysts have a rather constant composition close to bytownite $\mathrm{An}_{85}$. Core-to-rim compositional variations are of limited importance $(2-5 \%$ anorthite) and predominantly of reverse type (Analyses $12-14$, Table 2). The extreme peripheries of the phenocrysts and the groundmass feldspars (Analyses 15-18) are more sodic (bytownite-labradorite $\mathrm{An}_{78-68}$ ). All the feldspars studied have low $\mathrm{K}$ and significant $\mathrm{Mg}$ contents, which appears to be characteristic of plagioclase from seafloor tholeiitic rocks (Hawkins, 1977).

Summarizing, the mineral composition Leg 66 basalt is typical of ocean floor tholeiites.

\section{TRACE ELEMENTS}

The trace element data of the three basaltic samples from Hole 487 are given in Table 3. Although they are not trace elements, the concentrations of $\mathrm{Ti}, \mathrm{Mn}$, and $\mathrm{Fe}$ have been converted to ppm to present all elements belonging to the first transition series in the same table. The elements are arranged in the order of increasing atomic number. All concentrations were determined by $\mathrm{X}$-ray spectrometry (XRF) up to $\mathrm{Nb}$, except $\mathrm{Sc}$, which was determined by neutron activation analysis (NA), and $\mathrm{Co}$ and $\mathrm{Ni}$, for which both XRF and $\mathrm{Na}$ data are available; from $\mathrm{Sb}$ to $\mathrm{U}$ all concentrations were obtained by $\mathrm{Na}$. 
Table 1. Basalt from Hole 487: Major elements and C.I.P.W. norms.

\begin{tabular}{|c|c|c|c|}
\hline $\begin{array}{c}\text { Sample } \\
\text { (interval in } \mathrm{cm} \text { ) }\end{array}$ & $\begin{array}{c}487-20-1 \\
55-58\end{array}$ & $\begin{array}{c}487-20-1 \\
72-78\end{array}$ & $\begin{array}{c}487-20-1 \\
82-89\end{array}$ \\
\hline $\mathrm{SiO}_{2}$ & 48.72 & 48.83 & 49.99 \\
\hline $\mathrm{TiO}_{2}$ & 0.84 & 0.86 & 0.84 \\
\hline $\mathrm{Al}_{2} \mathrm{O}_{3}$ & 16.33 & 16.72 & 16.68 \\
\hline $\mathrm{Fe}_{2} \mathrm{O}_{3}$ & 9.58 & 9.98 & 9.24 \\
\hline $\mathrm{MnO}$ & 0.14 & 0.16 & 0.14 \\
\hline $\mathrm{MgO}$ & 9.40 & 8.04 & 8.14 \\
\hline $\mathrm{CaO}$ & 13.24 & 13.44 & 13.33 \\
\hline $\mathrm{Na}_{2} \mathrm{O}$ & 2.45 & 1.65 & 2.05 \\
\hline $\mathrm{K}_{2}$ & 0.09 & 0.18 & 0.14 \\
\hline $\mathrm{P}_{2} \mathrm{O}_{5}$ & 0.08 & 0.11 & 0.09 \\
\hline Total & 100.87 & 99.97 & 100.64 \\
\hline \multicolumn{4}{|l|}{ Loss on ignition } \\
\hline $\begin{array}{c}1050^{\circ} \mathrm{C} \\
\text { Loss on ionition }\end{array}$ & 0.51 & 0.62 & 1.15 \\
\hline $1050^{\circ} \mathrm{C}$ & 0.01 & 0.53 & 0.86 \\
\hline Or & 0.53 & 1.07 & 0.83 \\
\hline$a b$ & 20.49 & 14.08 & 17.36 \\
\hline an & 33.28 & 38.02 & 35.95 \\
\hline ne & 0.12 & & \\
\hline (wo & 13.29 & 11.90 & 12.39 \\
\hline di $\{$ en & 8.43 & 7.13 & 7.64 \\
\hline fs & 4.01 & 4.15 & 4.03 \\
\hline en & & 10.48 & 9.40 \\
\hline Fs & & 6.10 & 4.97 \\
\hline Fo & 10.48 & 1.81 & 2.28 \\
\hline $\mathrm{Fa}$ & 5.50 & 1.16 & 1.33 \\
\hline $\mathrm{mt}$ & 2.09 & 2.19 & 2.02 \\
\hline il & 1.59 & 1.65 & 1.60 \\
\hline ap & 0.19 & 0.26 & 0.21 \\
\hline S.I. & 45.4 & 42.3 & 43.3 \\
\hline D.I. & 21.1 & 15.2 & 18.2 \\
\hline
\end{tabular}

Note: The norms are calculated with $85 \%$ of total iron as $\mathrm{FeO}$ and $15 \%$ as $\mathrm{Fe}_{2} \mathrm{O}_{3}$ (total $\mathrm{Fe}$ analysis is given as $\mathrm{Fe}_{2} \mathrm{O}_{3}$ ).

These data show the three samples to be very similar to one another and to be part of the same basaltic unit. This is not surprising, considering the restricted depth interval from which they were selected-Core 20-1, $55-89 \mathrm{~cm}$ ); only the three alkali elements show significant differences: $\mathrm{K}_{2} \mathrm{O}$ (in Table 1) $-0.09 \%, 0.18 \%$, $0.14 \%$; Rb-0.4 ppm, $4.9 \mathrm{ppm}, 3.1 \mathrm{ppm}$; $\mathrm{Cs}-0.02$ $\mathrm{ppm}, 0.18 \mathrm{ppm}, 0.12 \mathrm{ppm}$. These well-correlated variations are not considered primary features of lavas but due to alteration processes. That concentrations of trace elements are within a homogeneous unit constant except for those of alkali metals has already been observedfor instance in Hole 395A, which showed slight alteration (Bougault et al., 1978; Bougault, Joron, and Treuil, 1979), and in holes at Sites 417-418, which showed strong alteration (Joron et al., 1979; Bougault, Cambon, et al., 1979). Our results, relative to wellpreserved material, show once more that alkali metals have to be analyzed very carefully in any attempt to determine oceanic tholeiite genesis, since only slight alteration of material considered to be fresh (based on ignition loss and thin section observations) can modify $\mathrm{Rb}$ and $\mathrm{Cs}$ concentrations by a factor of 10 .

The high partition coefficient elements $\mathrm{Cr}$ and $\mathrm{Ni}$ mirror the crystallization of ferromagnesian minerals from basaltic liquid; $\mathrm{Cr}$ and $\mathrm{Ni}$ concentrations vary, respectively, from 600 and $250 \mathrm{ppm}$, in primary liquids to 50 and $50 \mathrm{ppm}$, in differentiated liquids in oceanic tholeiites (Bougault et al., 1979). In this respect, the lavas in Hole 487 underwent moderate fractional crystallization.

The hygromagmaphile elements of transition series 1 , 2,3 , and 4 , all showing ions with an electronic structure of rare gaz (except V), are plotted in an extended "rare earth diagram"' (Bougault and Treuil, 1980) in Figure 1. The first significant feature of this basalt is its "depleted" character, normalized concentrations of the most hygromagmaphile elements ( $\mathrm{Th}, \mathrm{Ta}, \mathrm{Nb}$, and $\mathrm{La}$ ) being much lower than others. The second concerns the normalized $\mathrm{Ta} / \mathrm{La}$ (or $\mathrm{Nb} / \mathrm{La}$ ) ratio, which seems to be lower than 0.5 . A precise value of this normalized $\mathrm{Ta} / \mathrm{La}$ ratio cannot be given because of the very low level of concentrations of these elements in these samples; nevertheless, this value is definitely different from the chondritic value of (1) characteristic of oceanic basalts with slight, or no, rare-earth-enriched distributions and is probably close to the value 0.5 found in "typically depleted" oceanic tholeiites (Bougault and Treuil, 1980). In this respect the tholeiite recovered in Hole 487 is similar to tholeiites recovered at $22^{\circ} \mathrm{N}$ (Bougault et al., 1978) and $25^{\circ} \mathrm{N}$ (Joron et al., 1979) in the North Atlantic, at $9^{\circ} \mathrm{N}$ on the East Pacific Rise and Siqueiros fracture zone (Joron et al., 1980), and at $21^{\circ} \mathrm{N}$ during the French-American submersible dives and during DSDP Leg 65 (Cambon et al., in press).

The present data presented will be compared with other data from the Central America Trench Leg 67 in a forthcoming volume.

\section{REFERENCES}

Bougault, H., Cambon, P., Corre, O., et al., 1979. Evidence for variability of magmatic processes and upper mantle heterogeneity in the axial region of the Mid-Atlantic Ridge near $22^{\circ}$ and $36^{\circ} \mathrm{N}$. Tectonophysics, 55:11-34.

Bougault, H., Joron, J. L., and Treuil, M., 1979. Alteration, fractional crystallization, partial melting, mantle properties from trace elements in basalts recovered in the North Atlantic. In Talwani, M., Harrison, C. G., and Hayes, D. E. (Eds.), Deep Drilling Results in the Atlantic Ocean: Ocean crust: Maurice Ewing Series 2, A.G.U. Geodyn. Proj. Scientific Rept., 48:352-368.

Bougault, H., and Treuil, M., 1980. Mid-Atlantic Ridge: zero-age geochemical variations between Azores and $22^{\circ} \mathrm{N}$. Nature, 286 (No. 5770), 209-212.

Bougault, H., Treuil, M., and Joron, J. L., 1978. Trace elements in basalts from $23^{\circ} \mathrm{N}$ and $36^{\circ} \mathrm{N}$ in the Atlantic Ocean: fractional crystallization, partial melting and heterogeneity of the upper mantle. In Melson, W. G., Rabinowitz, P. D., et al., 1978. Init. Rept. DSDP, 45: Washington (U.S. Govt. Printing Office), 493506.

Cambon, P., Joron, J. L., Bougault, H., et al., in press. Leg 65: East Pacific Rise-typical oceanic crust depleted in hygromagmaphile elements. In Robinson, P., Lewis, B. T. R., et al., Init. Repts. $D S D P, 65$ : Washington (U.S. Govt. Printing Office).

Hawkins, J. W., Jr, 1977. Petrologic and geochemical characteristics of marginal basin basalts. In Talwani, M., and Pitman, W. C., III (Eds.). Island Arcs, Deep-Sea Trenches and Back-Arc Basins: Maurice Ewing Series 1: Washington (American Geophysical Union), pp. 355-366.

Joron, J. L., Bollinger, C., Quisefit, J. P., et al., 1979. Trace elements in Cretaceous basalts at $25^{\circ} \mathrm{N}$ in the atlantic ocean: alteration, mantle compositions and magmatic processes. In Donnelly, T., 
Francheteau, J., Bryan, W., Robinson, P., Flower, M., Salisbury, M., et al., Init. Repts. DSDP, 51, 52, 53, Pt. 2: Washington (U.S. Govt. Printing Office), 1087-1098.

Joron, J. L., Briqueu, L., Bougault, H., et al., 1980. East Pacific Rise, Galapagos spreading center and Siqueiros fracture zone, Deep Sea Drilling Project Leg 54: hygromagmaphile elements-a com- parison with the North Atlantic. In Rosendahl, B. R., Hekinian, R., et al., Init. Repts. DSDP, 54: Washington (U.S. Govt. Printing Office), $725-735$

Sigurdsson, H., and Schilling, S. G., 1976. Spinels in Mid-Atlantic Ridge basalts: chemistry and occurrence. Earth Planet Sci. Lett., 29:7-20.

Table 2. Microprobe analyses of minerals from Sample 487-20-1, 55-58 cm.

\begin{tabular}{|c|c|c|c|c|c|c|c|c|c|}
\hline \multirow[b]{2}{*}{ Analysis } & \multicolumn{6}{|c|}{ Olivines } & \multicolumn{3}{|c|}{ Spinels } \\
\hline & 1 & 2 & 3 & 4 & 5 & 6 & 7 & 8 & 9 \\
\hline $\mathrm{SiO}_{2}$ & 40.79 & 40.57 & 40.49 & 40.47 & 41.03 & 40.09 & 0.48 & 0.98 & 0.60 \\
\hline $\mathrm{TiO}_{2}$ & 0.00 & 0.00 & 0.02 & 0.00 & 0.00 & 0.02 & 0.37 & 0.33 & 0.29 \\
\hline $\mathrm{Al}_{2} \mathrm{O}_{3}$ & 0.07 & 0.08 & 0.04 & 0.01 & 0.00 & 0.03 & 32.99 & 32.88 & 31.00 \\
\hline $\mathrm{Cr}_{2} \mathrm{O}_{3}$ & 0.03 & 0.00 & 0.00 & 0.07 & 0.15 & 0.00 & 33.51 & 32.90 & 33.38 \\
\hline $\mathrm{FeO}$ & 10.86 & 10.72 & 10.41 & 10.97 & 10.93 & 14.20 & 15.41 & 15.72 & 17.11 \\
\hline $\mathrm{MnO}$ & 0.17 & 0.27 & 0.21 & 0.03 & 0.20 & 0.23 & 0.00 & 0.31 & 0.07 \\
\hline $\mathrm{MgO}$ & 48.51 & 47.39 & 48.41 & 47.37 & 47.48 & 45.01 & 17.04 & 16.74 & 16.18 \\
\hline $\mathrm{CaO}$ & 0.31 & 0.31 & 0.39 & 0.32 & 0.41 & 0.38 & 0.06 & 0.18 & 0.38 \\
\hline $\mathrm{Na}_{2} \mathrm{O}$ & 0.00 & 0.00 & 0.00 & 0.00 & 0.03 & 0.01 & 0.00 & 0.07 & 0.00 \\
\hline $\mathrm{K}_{2} \mathrm{O}$ & 0.00 & 0.00 & 0.00 & 0.02 & 0.00 & 0.00 & 0.02 & 0.00 & 0.00 \\
\hline Total & 100.74 & 99.34 & 99.97 & 99.26 & 100.23 & 99.97 & 99.88 & 100.11 & 99.01 \\
\hline \multirow[t]{2}{*}{$\mathrm{FM}$} & 0.113 & 0.115 & 0.110 & 0.115 & 0.116 & 0.152 & 0.273 & 0.281 & 0.293 \\
\hline & \multicolumn{2}{|c|}{ Pyroxenes } & \multicolumn{7}{|c|}{ Plagioclases } \\
\hline Analysis & 10 & 11 & 12 & 13 & 14 & 15 & 16 & 17 & 18 \\
\hline $\mathrm{SiO}_{2}$ & 48.41 & 48.04 & 47.17 & 47.13 & 47.14 & 51.58 & 49.27 & 49.97 & 51.43 \\
\hline $\mathrm{TiO}_{2}$ & 1.90 & 1.87 & 0.10 & 0.00 & 0.00 & 0.00 & 0.02 & 0.09 & 0.02 \\
\hline $\mathrm{Al}_{2} \mathrm{O}_{3}$ & 6.27 & 5.22 & 33.06 & 33.20 & 33.31 & 29.74 & 31.63 & 30.83 & 29.57 \\
\hline $\mathrm{Cr}_{2} \mathrm{O}_{3}$ & 0.28 & 0.22 & 0.00 & 0.00 & 0.00 & 0.03 & 0.11 & 0.01 & 0.00 \\
\hline $\mathrm{FeO}$ & 8.96 & 11.59 & 0.21 & 0.30 & 0.26 & 0.56 & 0.50 & 0.72 & 0.76 \\
\hline $\mathrm{MnO}$ & 0.10 & 0.32 & 0.00 & 0.00 & 0.00 & 0.00 & 0.01 & 0.00 & 0.00 \\
\hline $\mathrm{MgO}$ & 12.27 & 11.36 & 0.21 & 0.17 & 0.19 & 0.34 & 0.26 & 0.46 & 0.45 \\
\hline $\mathrm{CaO}$ & 21.55 & 20.63 & 17.26 & 17.24 & 17.23 & 14.18 & 15.52 & 14.81 & 14.16 \\
\hline $\mathrm{Na}_{2} \mathrm{O}$ & 0.22 & 0.36 & 1.78 & 1.63 & 1.52 & 3.19 & 2.66 & 2.81 & 3.57 \\
\hline $\mathrm{K}_{2} \mathrm{O}$ & 0.06 & 0.00 & 0.01 & 0.00 & 0.00 & 0.00 & 0.00 & 0.02 & 0.03 \\
\hline Total & 100.02 & 99.61 & 99.80 & 99.67 & 99.65 & 99.62 & 99.98 & 99.72 & 99.99 \\
\hline $\mathrm{Ca}$ & 47.2 & 45.1 & & & & & & & \\
\hline $\mathrm{Mg}$ & 37.3 & 34.6 & & & & & & & \\
\hline $\mathrm{Fe}+\mathrm{Mn}$ & 15.5 & 20.3 & & & & & & & \\
\hline $\mathrm{Ca}$ & & & 84.2 & 85.4 & 86.3 & 71.1 & 76.3 & 74.4 & 68.5 \\
\hline $\mathrm{Na}$ & & & 15.8 & 14.6 & 13.7 & 28.9 & 23.7 & 25.5 & 31.3 \\
\hline $\mathrm{K}$ & & & 0.0 & 0.0 & 0.0 & 0.0 & 0.0 & 0.1 & 0.2 \\
\hline
\end{tabular}

Note: All analyses have been obtained with a Camebax automated microprobe (Microsonde Ouest, Brest), working conditions $15 \mathrm{kV}, 10-12 \mathrm{nA}$, counting time $6 \mathrm{~s}$. Concentrations lower than $0.1 \%$ are not considered representative. Total iron expressed as FeO. Olivines: 1.2 (core and rim of a $400-\mu \mathrm{m}$ phenocryst); 3.4 (core and rim of a 300- $\mu \mathrm{m}$ phenocryst); 5.6: groundmass. Spinels: 7.8 (core and rim of a 20$\mu \mathrm{m}$ crystal); 9: small crystal $(5 \mu \mathrm{m})$. Pyroxenes: 10, 11 (groundmass). Plagioclases: 12-15 (core-to-rim zonation of a $150-\mu \mathrm{m}$ phenocryst); 16-18: microlites.

Table 3. Trace element data (ppm), Hole 487.

\begin{tabular}{|c|c|c|c|c|c|c|c|c|c|c|c|c|c|}
\hline $\begin{array}{c}\text { Sample } \\
\text { (interval in } \mathrm{cm} \text { ) }\end{array}$ & $\begin{array}{l}\mathrm{Sc} \\
\mathrm{NA}\end{array}$ & $\begin{array}{c}\mathrm{Ti} \\
\text { XRF }\end{array}$ & $\begin{array}{c}\mathrm{V} \\
\mathrm{XRF}\end{array}$ & $\begin{array}{c}\mathrm{Cr} \\
\text { XRF }\end{array}$ & $\underset{\text { XRF }}{\mathrm{Mn}}$ & $\begin{array}{c}\mathrm{Fe} \\
\mathrm{XRF}\end{array}$ & $\underset{\mathrm{XRF}}{\mathrm{Y}}$ & $\begin{array}{c}\mathrm{Zr} \\
\mathrm{XRF}\end{array}$ & $\begin{array}{l}\mathrm{Nb} \\
\mathrm{XRF}\end{array}$ & $\begin{array}{l}\mathrm{Sb} \\
\mathrm{NA}\end{array}$ & $\begin{array}{l}\mathrm{Cs} \\
\mathrm{NA}\end{array}$ & $\begin{array}{l}\mathrm{Ba} \\
\mathrm{NA}\end{array}$ & $\begin{array}{l}\mathrm{La} \\
\mathrm{NA}\end{array}$ \\
\hline $20-1,55-58$ & 34.0 & 5040 & 236 & 451 & 1084 & 70605 & 26 & 48 & 0.3 & 0.03 & 0.02 & 5.2 & 0.75 \\
\hline $20-1,72-78$ & 33.9 & 5160 & 255 & 461 & 1239 & 73553 & 27 & 56 & 0.6 & 0.20 & 0.18 & & 0.80 \\
\hline $20-1,82-89$ & 33.4 & 5040 & 237 & 447 & 1084 & 68098 & 26 & 44 & 0.4 & 0.08 & 0.12 & & 0.83 \\
\hline \multirow{2}{*}{$\begin{array}{c}\text { Sample } \\
\text { (interval in } \mathrm{cm} \text { ) }\end{array}$} & $\mathrm{Ce}$ & \multicolumn{2}{|c|}{ Co } & \multicolumn{2}{|c|}{$\mathrm{Ni}$} & $\mathrm{Zn}$ & $\mathrm{Rb}$ & $\mathrm{Sr}$ & Eu & $\mathrm{Tb}$ & $\mathrm{Hf}$ & $\mathrm{Ta}$ & TH \\
\hline & $\mathrm{NA}$ & XRF & NA & XRF & NA & XRF & XRF & XRF & $\mathrm{NA}$ & NA & NA & NA & NA \\
\hline $20-1,55-58$ & & 44 & 45 & 138 & 144 & 62 & 0.4 & 54 & 0.81 & 0.47 & 1.07 & 0.033 & 0.013 \\
\hline $20-1,72-78$ & & 45 & 45 & 119 & 127 & 61 & 4.9 & 56 & 0.72 & 0.48 & 1.17 & 0.029 & 0.022 \\
\hline $20-1,82-89$ & 1.6 & 46 & 46 & 129 & 136 & 60 & 3.1 & 56 & 0.66 & 0.43 & 1.16 & 0.028 & 0.042 \\
\hline
\end{tabular}


J. L. JORON, H. BOUGAULT, R. C. MAURY, J. F. STEPHAN

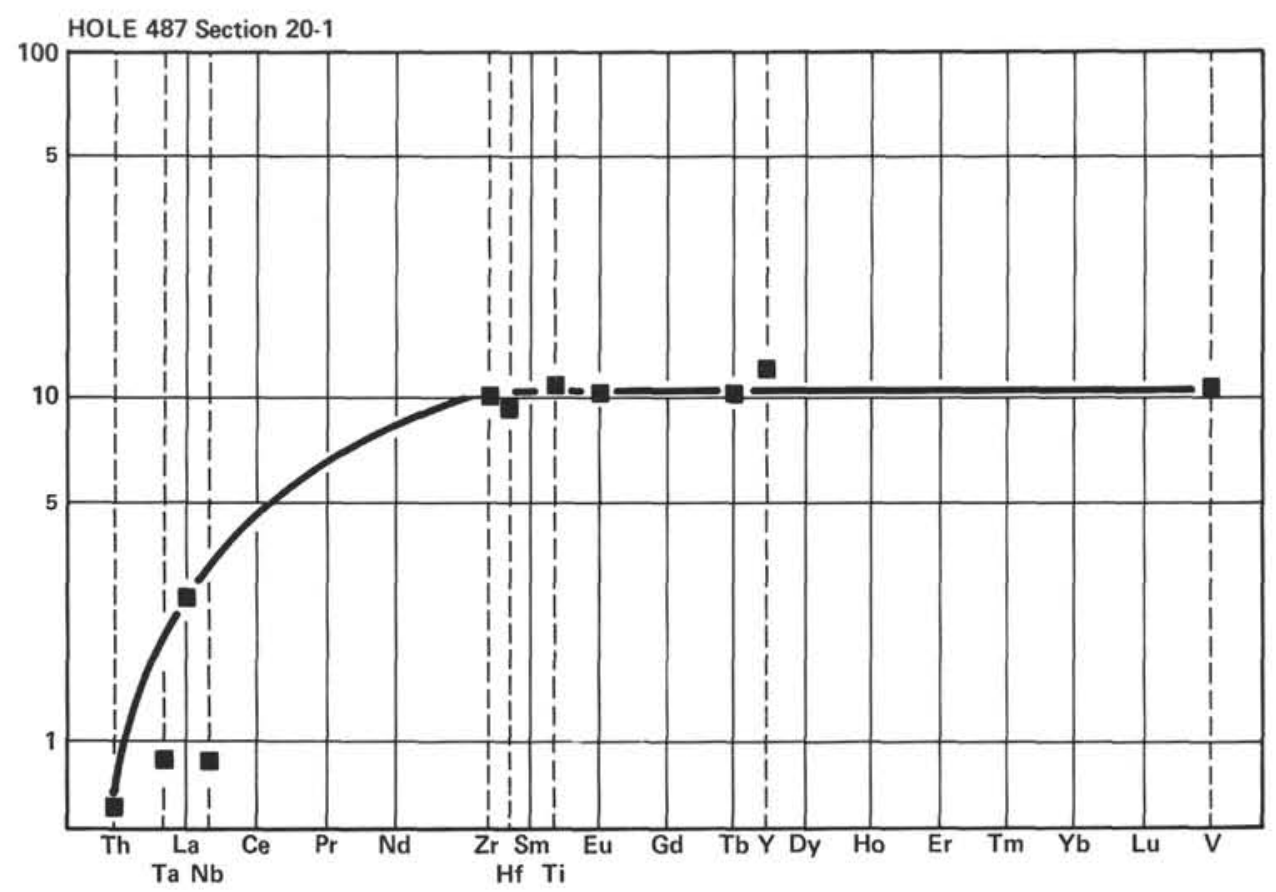

Figure 1. Hole 487: extended rare earth diagram showing the depleted character of the basalts recovered in this hole. 